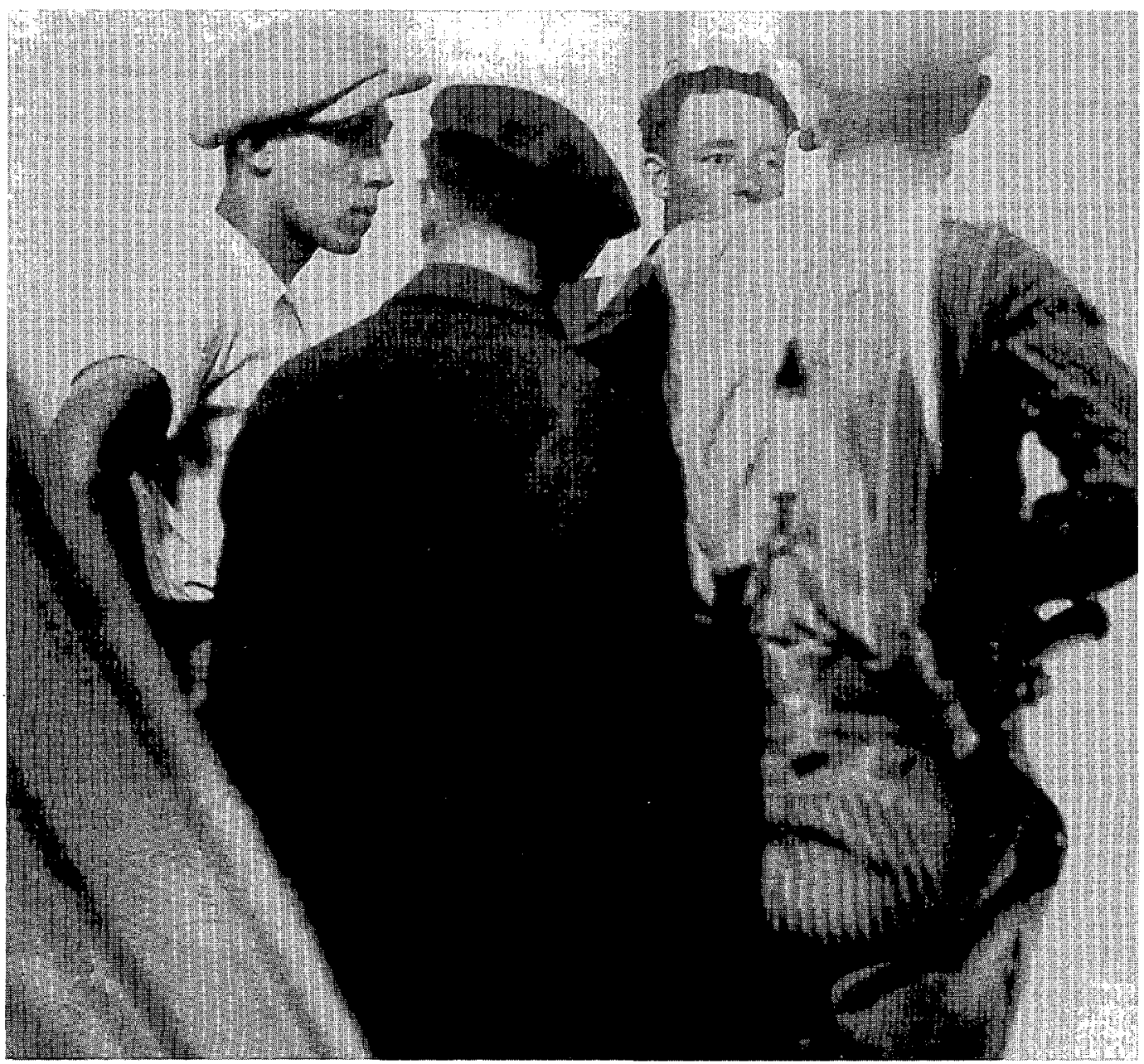

Mijnwerkers in de Borinage 


\section{Vakbonden en etnische minderheid, een ambigue verhouding. Immigratie in de Belgische mijnbekkens, $1900-1940$}

\author{
Frank Caestecker, Institut für \\ Migrationsforschung und Interkulturelle \\ Studien, Universität Osnabrück (1)
}

Etnische, net zoals andere categorieën (Vlaming, Waal, Pool ... of arbeider) zijn geconstrueerde categorieën. Zij maken een onderverdeling in de sociale werkelijkheid die daarom in de alledaagse werkelijkheid van de betrokkenen die waarde niet moet hebben. De etnische categorie is in de sociale wetenschappen van de jaren '90 dé categorie (samen met gender), net zoals klasse de categorie van de jaren' 60 en' 70 was. Deze nieuwe kijk op de sociale werkelijkheid maakt dat ook het verleden op een andere wijze wordt geïnterpreteerd, op een meer complexe wijze. Historici onderzochten tot voor kort de arbeidersbeweging zonder de ongemene complexiteit van de arbeiderswereld in overweging te nemen. In het bijzonder voor België, met zijn grote vrouwelijke arbeidsparticipatie en een multi-etnische samenstelling van de arbeiderspopulatie, betekende dit een gevoelige verarming van de sociale werkelijkheid waarbinnen de arbeidersbeweging zich situeerde.

Het analyseren van de diversiteit van zowel de arbeiderswereld als haar organisatorische uitingen dringt zich op om een meer adequaat beeld te krijgen van de historische veranderingen.
Deze bijdrage vertrekt van de multi-etnische samenstelling van de arbeiderspopulatie van de mijnindustrie en gaat na of deze geleid heeft tot verdeeldheid onder de arbeiders. Centraal hierbij is in welke mate de Belgische mijnwerkersvakbonden deze multi-etnische samenstelling ontkend of gevaloriseerd hebben. Een multi-etnisch samengestelde arbeidersgroep kan gemakkelijk leiden tot fragmentatie van de arbeidersgroep, maar kan ook een sterk àrbeidersfront doen ontstaan, een front steunend op een alliantie tussen etnische groepen ${ }^{(2)}$. Etnische solidariteit kan immers het vakbondsbewustzijn meer inhoud geven. Het ontkennen van de multi-etniciteit, wat de keuze voor de dominante etniciteit inhoudt, kan daarentegen de etnische verdeeldheid aanscherpen.

\section{Alle mijnwerkers zijn immigranten}

België is sinds het begin van deze eeuw een immigratieland. Inwijking in België was tot de jaren' 50 vooral het gevolg van de economische aantrekkingskracht van de mijnindustrie. In de $19 \mathrm{de}$ eeuw kende de mijnindustrie een enorme expan- 
sie. Het aantal mijnwerkers explodeerde van 30.000 in 1830 tot 150.000 in 1914. Deze spectaculaire stijging was enkel mogelijk door een massale migratie naar de mijnbekkens. Reeds rond 1860 waren de mijnwerkers in het Boreinse bekken geen vlottende massa meer. Er had zich een stam van mijnwerkers gevormd, mijnwerkers die van vader op zoon naar de mijn trokken. Deze stam verzekerde de zelf-reproductie van de mijnwerkers. In de andere Waalse bekkens kan men slechts spreken van een stabiele kern van mijnwerkers rond 1880 . Het is in deze mijnwerkersgemeenschappen dat het organisatie-idee wortel schoot. Deze mijnwerkers uit traditie sloten zich rond de eeuwwisseling massaal aan bij de socialistische Mijnwerkerscentrale. Eén op drie mijnwerkers was toen georganiseerd.

Deze kern van lokaal gerekruteerde mijnwerkers die van vader opzoon in de mijn werkten werdook na 1880 , door de blijvende expansie van de mijnindustrie aangevuld met nieuwkomers. Vooral de grote arbeidsreserves in Vlaanderen werden aangeboord. De economische neergang op het einde van de $19 \mathrm{de}$ eeuw - in de eersteplaats een agrarische depressie - maakte dat heel wat Vlaamse kleine boeren de eindjes niet meer aan elkaar konden knopen. Vele Vlamingen moesten zich vestigen in de Waalse mijnbekkens om in hun levensonderhoud te kunnen voorzien. Goedkope spoorwegabonnementen boden heel wat Vlamingen evenwel een alternatief. $\mathrm{Zij}$ konden hun brood verdienen in Wallonië, maar een vestiging in Wallonië was niet noodzakelijk. Zij pendelden wekelijks of dagelijks naar de mijn. $\mathrm{Na}$ de Eerste Wereldoorlog zorgden de achturendag en de hogere lonen ervoor dat het dagelijkse pendelen voor nog meer Vlamingen loonde. Een vestiging in Wallonië werd minder noodzakelijk.

Rond de eeuwwisseling was de aantrekkingskracht van de Waalse steenkoolmijnen reeds uitgedijd over het gehele land. De nationale arbeidsmarkt kon evenwel niet aan de steeds stijgende arbeidsnoden van de zware industrie blijven vol- doen. In de jaren ' 20 werd met de exploitatie van het Kempische mijnbekken gestart. In 1930 stelde de mijnindustrie bijna 200.000 personen te werk. Demografische veranderingen onder de traditionele Waalse mijnwerkerspopulatie - een kleiner kinderaantal - samen met meer gediversifieerde beroepsmogelijkheden, ook in Vlaanderen, maakten dat heel wat traditioneel voor de mijn bestemde Belgische arbeidskrachten zich afwendden van deze bedrijfstak. De gevaarlijke en zware arbeidsvoorwaarden en de daarom niet veel hogere lonen, samen met het lage sociale prestige van het mijnwerk maakten dat velen verkozen niet meer in de voetsporen van hun ouders te treden $^{(3)}$.

De mijnindustrie zag zich gedwongen om arbeidskrachten over de nationale grens heen aan te werven. In de buurlanden was het aanbod aan beschikbare arbeidskrachten gering. Reeds in het jaar 1910, maar vooral in het volgende decennium leverden Zuid- en Oost-Europa (Italië, Polen, Joegoslavië en Tsjechoslovakije) massaal arbeidskrachten aan de Belgische mijnindustrie. Deze Polen, Italianen... boden zich niet zomaar spontaan aan. De industriëlen onderhandelden met de autoriteiten van deze landen of stuurden er zelfs agenten heen om mensen te overtuigen van de kansen die België hun bood. De reis was voor zij die toehapten gratis, de ondernemingen namen deze te hunnen laste.

De werkgevers beoogden met het aanboren van reserves aan arbeidskrachten in de periferie van Europa niet enkel hun arbeidsaanbod kwantitatief, maar ook kwalitatief te verhogen. Zij beoogden niet enkel hun arbeidstekort aan te vullen, maar ook 'betere' arbeidskrachten te verwerven. In het bijzonder het Limburgse mijnpatronaat wilde door een selectieve aanwervingspolitiek, aangevuld met een multicultureel personeelsbeleid de buitenlandse arbeidskrachten tot betrouwbare arbeidskrachten maken. Het moesten arbeidskrachten worden op wie de werkgevers konden rekenen, ook in de toekomst. De kin- 
deren van deze Poolse, Italiaanse... immigranten moesten de mijnwerkers van morgen worden. De buitenlandse arbeidskrachten moesten niet enkel betrouwbaar zijn in economische zin, maar ook op sociaal vlak. Immigranten moesten vertrouwen hebben in hun werkgevers. Het mijnpatronaat wilde vermijden dat zijn nieuwe arbeidskrachten zich verenigden met de Belgische arbeiders om hun belangen te verdedigen. De vakbonden werden door de patroons in de mijnindustrie immers als hun klassevijand beschouwd, niet als hun partner.

\section{De vakbonden en immigratie}

Hoe hebben de vakbonden nu gereageerd opdeze patronale uitdaging? Het antwoord van de vakbonden was tweeërlei: enerzijds het organiseren van de buitenlandse arbeidskrachten, anderzijds een beroep doen op de staat om de immigratie te reguleren. In dit artikelzullen weons beperken tot de organisatie van de immigranten. Wel kon het bepleiten door de vakbonden van een restrictief immigratiebeleid bij de staat de organisatie van de buitenlandse arbeiders belemmeren. In periodes van toenemende werkloosheid bepleitten de vakbonden immers niet alleen een immigratiestop, waardoor de buitenlandse arbeiders familie en vrienden niet meer konden laten overkomen, maar ook de repatriëring van werkloze immigranten. Soms eisten de vakbonden zelfs het ontslag van de buitenlandse arbeidskrachten om de Belgische arbeiders te vrijwaren voor werkloosheid. Vele immigranten vonden dan ook dat de vakbonden niet hun belangen, maar enkel die van hun Belgische collega's verdedigden ${ }^{(4)}$.

Het uitbouwen van een gemeenschappelijk arbeidersfront door de organisatie, vorming en mobilisatie van alle werknemers ongeacht herkomst, was een strategie die door de vakbonden onderschreven werd in de hier behandelde periode. Zowel de christen-democratische - de Vrije Mijnwerkers - als de socialistische vakbond - de
Mijnwerkerscentrale - stelden dat zij alle mijnwerkers in België wilden organiseren en hun belangen zonder onderscheid verdedigen. In welke mate de vakbonden bij de mobilisatie van de immigranten rekening hielden met het anders-zijn van deze arbeiders en in welke mate ze dit anderszijn valoriseerden is sterk uiteenlopend in tijd en ruimte.

\section{Vlaamse migranten}

De eerste migranten met wie de mijnwerkersvakbonden geconfronteerd werden waren de Vlamingen. DeVrije Mijnwerkers opteerde van meet af aan voor een gescheiden vakbondswerking voor deze immigranten. De christen-democratische mijnwerkersvakbond stelde reeds in oktober 1908 een Vlaamse propagandist aan in La Louvière ${ }^{(5)}$. De Vlaamse immigranten in Wallonië werden georganiseerd in een aparte structuur met een autonoom syndicaal leven. De positieve houding vande $V$ rije Mijnwerkers tegenoverdeze etnische minderheid in Wallonië leidde tot een voorzichtige doorbraak van deze vakbond in de tot dan toe louter en alleen socialistisch georganiseerde mijnbekkens.

De Mijnwerkerscentrale beschouwde de Vrije Mijnwerkers als een machinatie van de katholieke clerus en het mijnpatronaat om de arbeidersmacht in de mijnindustrie te breken. Alhoewel de Vrije Mijnwerkers inderdaad een weinig authentieke arbeiderscreatie was emancipeerde deze organisatie snel tot een autonome arbeidersorganisatie die door haar Vlaamse propaganda in Wallonië een plaatselijke aanhang kon verwerven. De Mijnwerkerscentrale negeerde de Vlaamse immigranten in Wallonië als groep totaal. $Z_{i j}$ moesten hun eigenheid als groep opgeven. Elkeen moest zich totaal aanpassen om deel te worden van de socialistische beweging. $\mathrm{Zij}$ moesten tegelijkertijd gelaïciseerd, gefranciseerd en gesyndicaliseerd worden.

Een aalmoezenier van de Vlamingen beschreef de ongemeen zware assimilatiedruk waataan zijn 


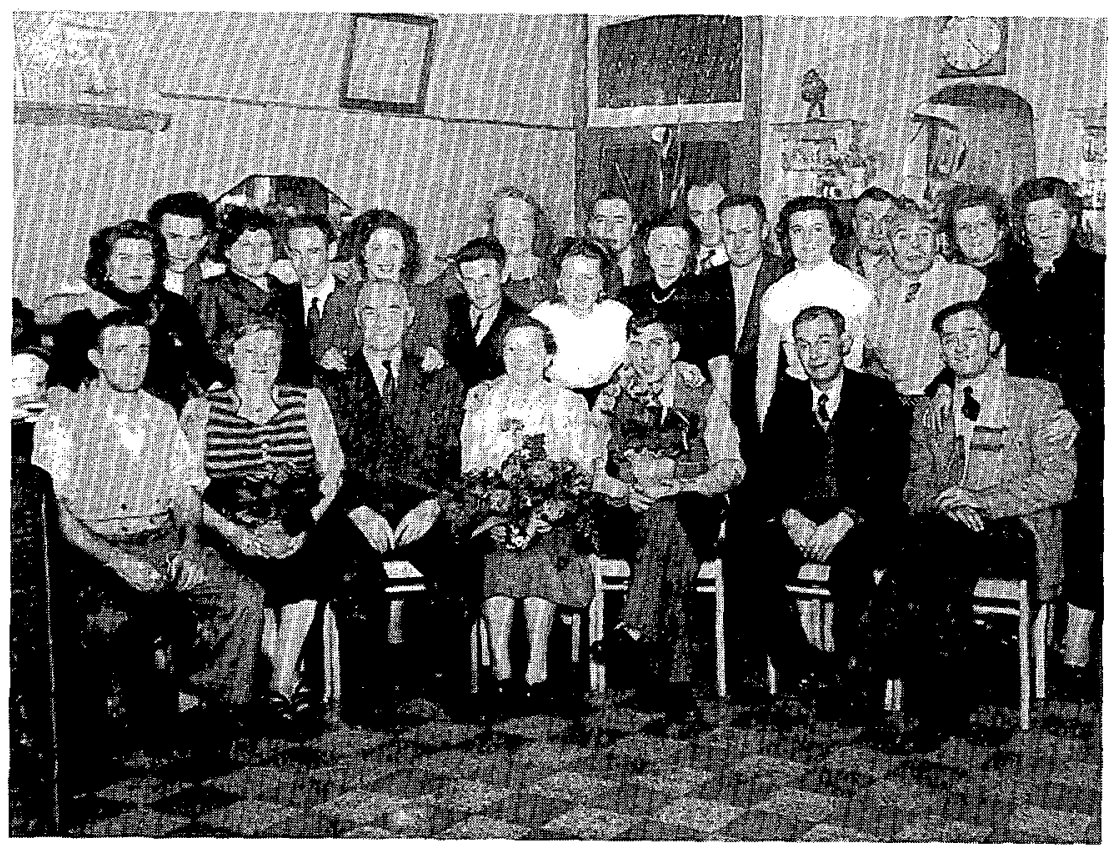

Mijnwerkers uit Roeselare

Vlaamse parochianen blootstonden in volgende termen:

"Onze menschen blijven hier ware achteruitgestelden. Zij blijven beschouwd als een minder ras bij zooverre dat na eenige maanden verblijf hier onze kinderen op de school niet meer zeggen durven dat ze Vlaamsche kinderen zünn" (6).

Desocialistische mijnwerkersbond repliceerdede etnische machtsverhoudingen in het 19deeeuwse België. Deze assimilatiestrategie maakte dat er geen specifieke inspanningen werden geleverd om de Vlaamse arbeidsmigranten te bereiken. Alhoewel er reeds vanaf 1900 stemmen opgingen om het vakbondsblad ook voor de Vlaamse mijnwerkers toegankelijk te maken werd hier slechts op ingegaan in 1910. Slechts dan werd 'Ouvrier Mineur vertaald in het Nederlands (7). Deze beslissing kaderde veeleer in een propaganda-offensief gericht op de Vlaamse pendelarbeiders. Voor de arbeiders die dagelijks uit Geraardsbergen, Ronse...naar de mijnen kwamen kon niet gerekend worden op de heilzame werking van de assimilatie. Zij waren en bleven Vla- mingen en van hen syndicalisten maken vereiste een meer gedifferentieerde strategie. Voor deze Vlamingen werden aparte vakbondssecties opgeriche. Voor de Vlamingen die zich vestigden in Wallonië werd geen categorisch beleid ontwikkeld.

Een Vlaamse propagandist voor de Vlaamse mijnwerkers in de Waalse bekkens werd afgewezen, evenals het organiseren van deze Vlamingen in aparte vakbondssecties ${ }^{(8)}$. Alle hoop werd gesteld in het assimilatieproces. Het verblijf in de mijnbekkens en het dagdagelijkse contact met de Waalse mijnwerkers moest deze Vlamingen doen verdwijnen. $\mathrm{Zij}$ moesten herboren worden als leden van de lokale arbeiderscultuur.

Het sterke geloof in het assimilatievermogen van het socialistische Wallonië werd in 1938 vertolkt door de Luikse senator Van Belle in zijn bijdrage aan het Eerste Congres van de Waalse socialisten. Dit congres dat op zich reeds een uiting was van de verschuivingen in de etnische machtsverhoudingen introduceerde voor het eerst de Vlamingen in Walloniëals thema op de socialistische 
agenda in het Zuiden van het land. Van Belle stelde dat de mentaliteit van de Vlamingen die zich gevestigd hadden in Wallonië zich grondig had gewijzigd. Zij waren opgegaan in de Waalse arbeidersgemeenschap. Deze Vlaamse arbeiders gevestigd in Wallonië betoonden volgens hem geen enkele interesse voor het behouden van hun Vlaamse eigenheid. De Vlaamse organisaties zouden voor hen geen enkele aantrekkingskracht hebben. Hij stelde: "Ils préfèrent eux-mêmes se confondre avec les ouvriers wallons dans les mêmes assemblées. Au surplus, nous les surprenons très souvent à parler wallon entre eux". De aanhang van de christen-democratische organisaties onder de Vlamingen woonachtig in Walloniëondermijnde evenwel zijn geloof in de almacht van de assimilatie ${ }^{(9)}$.

Van Belle vertolkte op dit congres hetzelfde standpunt als de leiding van de Mijnwerkerscentrale. Hij verwierp het christen-democratische organisatieprincipe. De Vlaamse leden apart organiseren was uit den boze. Enige hulp bij de assimilatie was wel opportuun. Af en toe een vergadering organiseren specifiek voor de Vlaamse arbeiders en het aanstellen van propagandisten die het Vlaams machtig waren zou voldoende moeten zijn om de Vlamingen in Wallonië massaal tot de socialistische organisaties te doen toetreden. De bouwcentrale, die een stijgend aantal Vlamingen op de Luikse bouwwerven zag verschijnen, besloot in 1929 een Vlaamse propagandist, Julien Van Craen, aan te werven. De nieuwe propagandist boekte snel resultaten, de syndicalisatiegraad van de Vlaamse bouwvakkers werkzaam in het Luikse steeg beduidend in de volgende jaren. In juli 1933 werd in de Fédération Générale des Syndicats de Liège door Yansenne voorgesteld om een Vlaamse secretaris voor de Luikse regio aan te stellen. Zijn voorstel werd niet weerhouden. De klassieke argumenten werden bovengehaald : er woonden geen Vlamingen in het Luikse, de enige Vlaamse arbeiders in deze provincie waren de pendelarbeiders. Deze kwamen dagelijks met de trein aan en gingen on- middellijk naar de fabriek of de mijn. Wanneer hun dagtaak erop zat vertrokken ze onmiddellijk terug naar Vlaanderen. Propaganda onder hen in het Luikse was niet mogelijk. De realiteit van de Vlaamse arbeidsmigranten in Wallonië werd totaal genegeerd. Deze verwaarlozing in een periode van opkomend Vlaams bewustzijn legde de christen-democratische organisaties in Wallonië geen windeieren. Hun aanhang in Wallonië nam gevoelig toe.

De Vlaamse syndicalist Van Dorsselaar klaagde in 1936 in Volksgazet de nalatigheid van de Waalse syndicalisten aan. De Vlaamse arbeiders in Wallonië waren het monopolie van de christen-democraten geworden. Terwijl de christen-democraten alles in het werk stelden om de Vlaamse arbeiders in Wallonië te organiseren, lieten de socialisten dit rekruteringsveld braak liggen. Het was dringend nodig dat ook de socialisten in Wallonië een inspanning deden om deze arbeiders te verenigen. Bijna tien jaar na de bouwcentrale, in 1938, besloot de Luikse mijnwerkerscentrale een propagandist aan te werven voor de Vlaamse mijnwerkers in dit bekken ${ }^{(10)}$. Een categorisch beleid werd na vier decennia intensieve migratie uit Vlaanderen naar Wallonië dan toch opportuun geacht.

\section{Buitenlandse migranten}

Dit patroon, waarbij de christen-democratische vakbondsorganisaties de etniciteit van de immigranten in Wallonië als strategisch element opnamen binnen hun syndicale strategie, terwijl de socialistische organisaties de etnische heterogeniteit van de arbeiderspopulaties straal negeerden, vinden we ook terug in de vakbondsstrategieën tegenover buitenlandse immigranten in de eerste helft van de jaren '20. De christen-democratische mijnwerkersvakbond opteerde van meet af aan voor een aparte vakbondswerking voor de vreemdelingen. De Poolse, Italiaanse...leden van de Vrije Mijnwerkers werden 


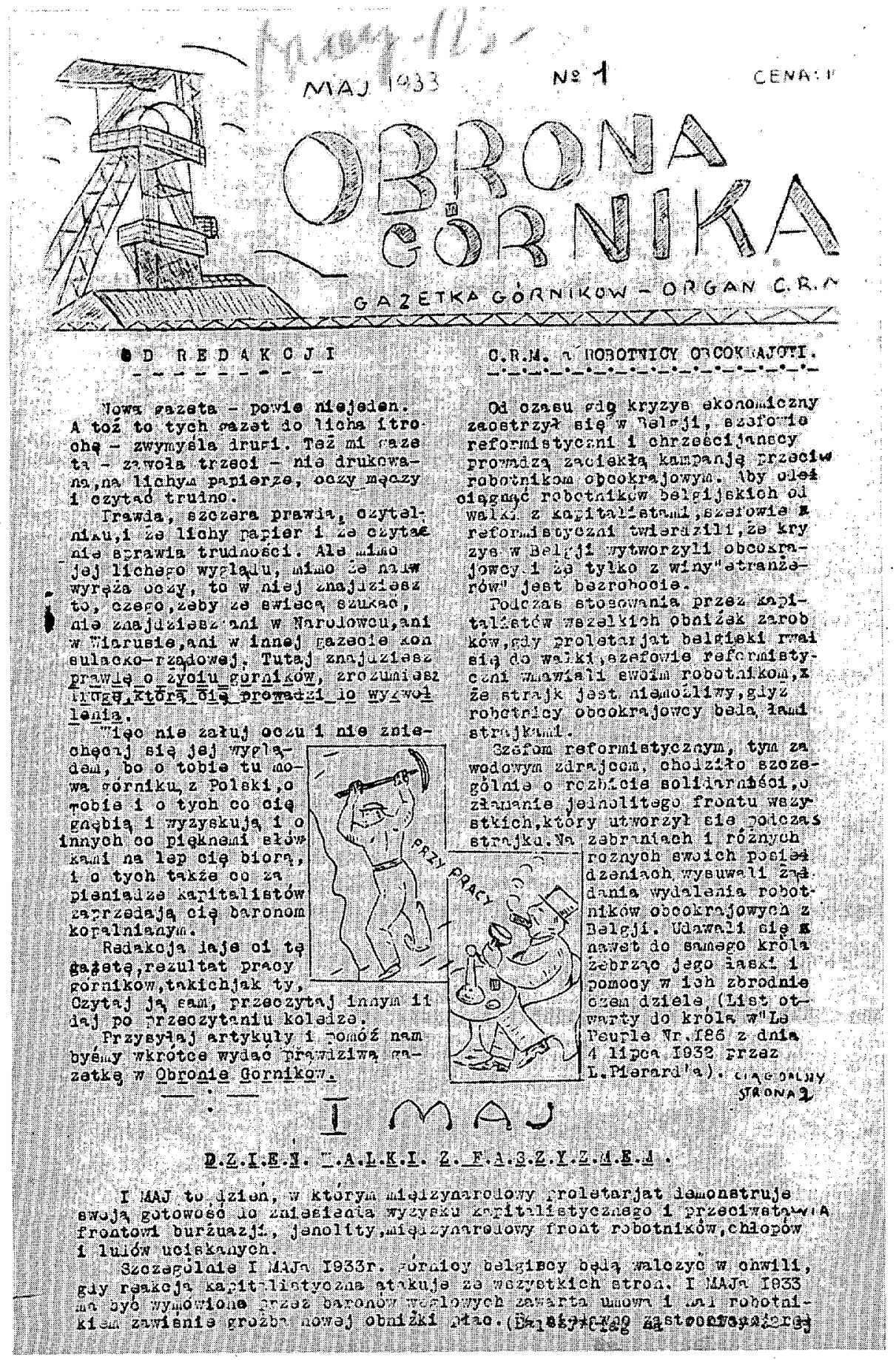

Pamflet voor het 1-meifeest van de Poolse mijnwerkers 
georganiseerd binnen een aparte structuur met een autonoom syndicaal leven. Per taalgroep werd een sectie opgericht met eigen kaderpersoneel en een eigen vakbondsblad ${ }^{(11)}$. Er werden geen institutionele kanalen voorzien voor deze secties om invloed uit te oefenen op de besluitvorming binnen de Vrije Mijnwerkers.

De socialistische mijnwerkersvakbond weigerde, in tegenstelling tor de Vrije Mijnwerkers, een onderschieid te maken tussen buitenlandse en Belgische arbeiders. Charles Suyvoet, de secretaris van de Limburgse Mijnwerkerscentrale meende dat de christen-democratische gescheiden organisatie enkel het arbeidersfront schaadde. Het betekende volgens hem immers geen enkele erkenning voor de buitenlanders, want het had enkelen alleen de bedoeling de Belgische arbeiders te behagen ${ }^{(12)}$. Deze visie werd blijkbaar niet gedeeld door de immigranten zelf. De christen-democratische vakbond boekte in ieder geval binnen de grootste migrantengemeenschap - de Poolse beduidend meer succes dan de Mijnwerkerscentrale. Deze Poolse aanhang van de Vrije Mijnwerkers zette kwaad bloed bij de socialisten. Dabrowski, een Pool die in opdracht van de PPS (de Poolse socialistische partij) een studiereis maakte in België om het indrukwekkende netwerk van socialistische coöperaties in België in kaart te brengen, kreeg in gesprekken met zijn Belgische kameraden het verwijt dat zijn landgenoten allesbehalve solidair waren met hun Belgische collega's. Dat de Poolse arbeidsmigranten toetraden tot de zogenaamde gele (katholieke) vakbond werd beschouwd als verraad van de arbeidersklasse. Dabrowksi wees er evenwel op dat de șocialistische vakbond geen enkele inspanning deed om de Poolse migranten te verenigen ${ }^{(13)}$. De Belgische socialisten meenden dat de Poolse migranten, net als de Vlaamse migranten, zich automatisch, uit klassesolidariteit, hoorden aan te sluiten bij de socialistische arbeidersorganisaties. Een categorisch beleid werd niet noodzakelijk geacht.
Pas in 1926 besloot de Syndikale Kommissie om de organisatie van de ingeweken arbeiders over een andere boeg te gooien. Er werd daarvoor onder meer contact opgenomen met de Poolse socialistische vakbond. De secretaris van de Poolse vakbond, A. Zdanowski, kwam in november 1926 naar België om de organisatie van de Poolse arbeiders te bespreken. De Belgische en Poolse Syndicale Kommissie sloten een overeenkomst, waarbij onder meer de aanstelling van een door beide vakbondsorganisaties gemeenschappelijk gefinancierde Poolse propagandist in het vooruitzicht werd gesteld. De Poolse vakbondsleden zouden georganiseerd worden in afzonderlijke syndicale afdelingen onder de voogdij van Belgische vakorganisaties. In tegenstelling tot de vakbondsafdelingen voor immigranten van de christen-democraten, zouden de socialistische migrantensecties wel invloed hebben op de besluitvorming binnen de vakbond. De Poolse arbeiders kregen voor hun afgevaardigde een zetel in het bestuur van de centrales ${ }^{(14)}$. Deze structuur moest zowel een betere propaganda onder de Poolse arbeiders mogelijk maken als de inspraak van de Poolse vakbondsleden in het beleid verzekeren.

Snel zou blijken dat het tweede luik van de PoolsBelgische overeenkomst - de inspraak van de immigranten - van ondergeschikt belang was voor de Belgische vakbondstop. Enkel en alleen om pragmatische redenen werd afgestapt van het zonder onderscheid integreren van de buitenlandse arbeiders in de vakbond. Pierre Van Maldere, lid van de Syndikale Kommissie verduidelijkte in de Belgische Vakbeweging de nieuwe strategie. De accenten die hij legt zijn typerend voor de ingesteldheid van de Belgische vakbondsleiding:

"' $t$ Is in de reeds bestaande organisaties dat de vreemde werklieden dienen gegroepeerd, omdat zij dezelfde belangen te verdedigen en dezelfde tegenstrevers als de Belgische arbeiders te bestrijden hebben. Doch, het zou nier mogen verboden worden in den schoot der 
vakbonden bijzondere afdeelingen op te richten, ten einde het aanwervings- en opvoedingswerk der buitenlandsche werkers te vergemakkelijken, zulks onder het toezicht en op den grondslag der beginselen van de centrale organisatie" (15).

Deze nieuwe vakbondsstrategie, die voor alle etnische groepen gold betekende enkel een pragmatische, geen principiële koerswijziging van de socialistische bond. De multi-etnische organisatievorm was enkel aangenomen om de buitenlandse mijnwerkers 'op te voeden en aan te werven', niet om hen als partner op te nemen in de vakbondsorganisatie.

Enkel in de Limburgse vakbondswerking bracht de nieuwe structuur een verschuiving van het machtscentrum met zich. Elke mijn kende een aantal nationale secties die een vertegenwoordiger stuurden naar het plaatselijke uitvoerend comité, dat dan op zijn beurt afgevaardigden stuurde naar het regionale comité ${ }^{(16)}$. Deze multietnische werking wierp snel vruchten af. De Limburgse mijnwerkerscentrale telde in 1928 vooral buitenlanders onder haar leden ${ }^{(17)}$. In de socialistische 1-meibetoging van 1928 stapten in Hasselt buitenlandse communisten en socialisten gezamenlijk op naast. hun Belgische kameraden. Het Poolse communistische blad De Stem van de Arbeid evoceerde het vertrek naar Hasselt van de arbeidersdelegatie uit Winterslag:

"Toen de trein het station van Winterslag verliet werd de internationale aangeheven door een bonte groep arbeiders. Zowel Polen, Belgen als Slovenen, Hongaren, Italianen en Tsjechen zongen het lied. Dat had men nog nooit meegemaakt in Limburg. " ${ }^{(18)}$

In de andere mijnbekkens kwam de campagne van de Mijnwerkerscentrale onder de buitenlandse arbeiders nauwelijks van de grond. Het ordewoord van de top om plaats en middelen vrij te maken voor de syndicalisatie van de buitenlandse mijnarbeiders werd nauwelijks opgevolgd. De weinige initiatieven die in de Waalse mijnbek- kens genomen werden om de Poolse, Italiaanse... immigranten te organiseren werden in de kiem gesmoord door een xenofobe basis ${ }^{(19)}$. Zo werden Poolse mijnwerkers die in Lambusart door militanten van de Mijnwerkerscentrale waren uitgenodigd op een vakbondsfeest weinig gastvrij onthaald.

"Kort nadat de Polen in de zaal binnenkwamen verhieven zich de stemmen: 'retoumez en Pologne!' De Polen vertrokken, zichzelf zwerend dat ze nooit meer naar een Belgisch feest zouden gaan." (20)

De militanten, tot de kaders toe van de socialistische beweging vonden het niet noodzakelijk de basis aan te zetten tot een meer met het socialisme overeenstemmende internationalistische ingesteldheid. Zelfs in de kolommen van de socialistische pers waren er uitingen van xenofobie: zo werd bv. de immigranten de schuld aangewreven van het toenemende aantal ongevallen in de mijnen ${ }^{(21)}$. Zij zouden ook totaal geen benul hebben van mijnwerk, buitenlanders waren "de la main-d'oeuvre de trente-sixième qualité." (22) Daarenboven hadden ze geen notie van hygiëne, ze stonken ${ }^{(23)}$. Ze werden in de socialistische pers ook beschuldigd van het verspreiden van venerische en 'exotische' ziekten. Geweld en misdaad werden soms ook als het 'monopolie' van migranten afgeschilderd ${ }^{(24)}$. Xenofobie, tot zelfs racistische uitspraken waren geen zeldzaamheid in de socialistische pers ${ }^{(25)}$.

Ook in Limburg was de xenofobie onder de Belgische arbeiders virulent. De immigranten werden er uitgemaakt voor Boche of Pruis - scheldwoorden die kort na de Eerste Wereldoorlog hevig emotioneel geladen waren - maar de leiding van de Limbugse Mijnwerkscentrale ondersteunde krachtdadig de multi-etnische strategie en tolereerde geen xenofobe uitspraken in haar persorganen $^{(26)}$.

Dit Limburgse exceptionalisme was onder meer het gevolg van het hoger aantal buitenlandse mijnwerkers in Limburg dan in de Waalse bek- 


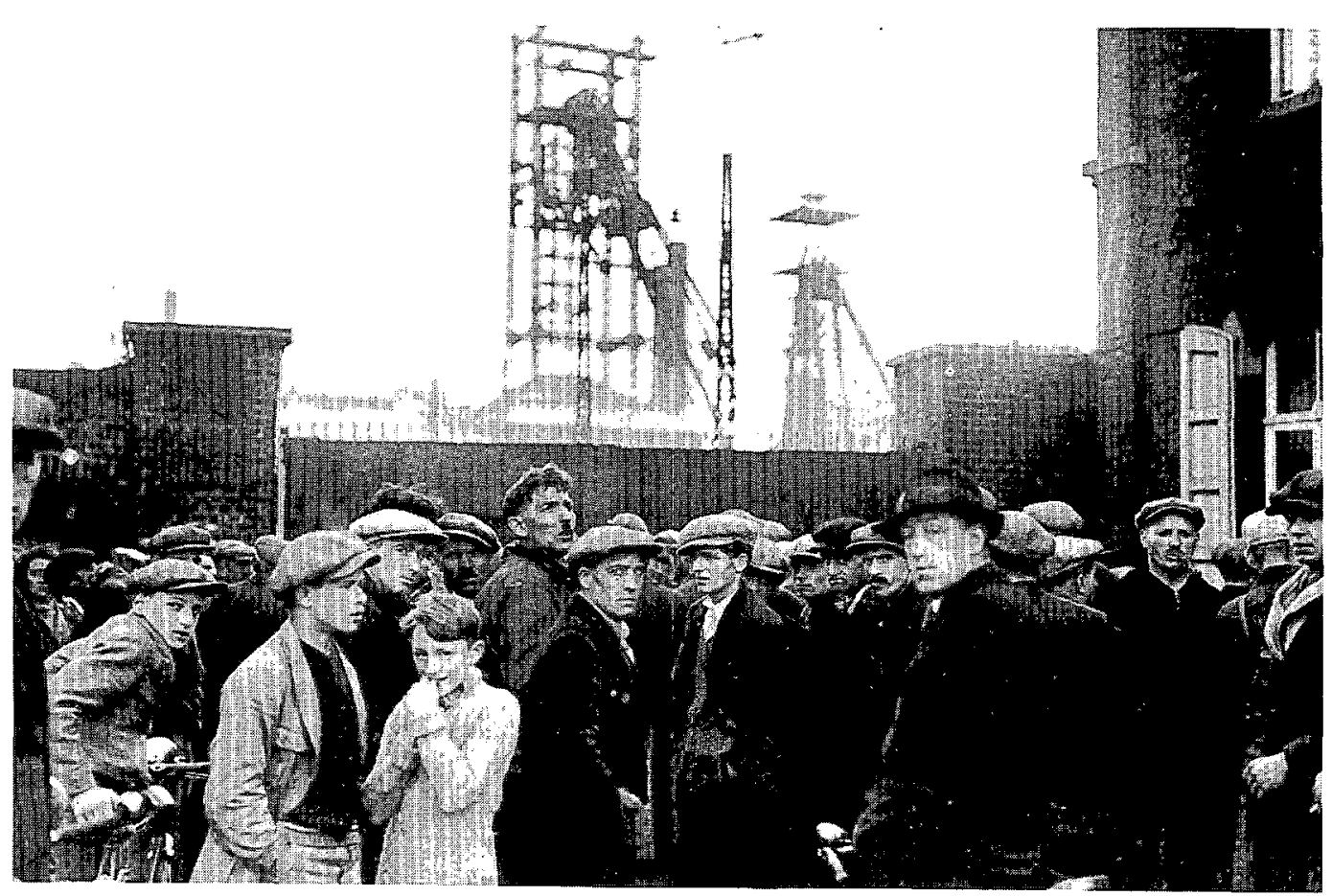

Tijdens de staking van 1932 in de Borinage eisten de lokale mijnwerkers bet vertrek van de Poolse arbeiders

kens ${ }^{(27)}$. De buitenlandse mijnwerkersgemeenschappen in Limburg waren ook wat meer geconcentreerd en wat homogener, maar cruciaal was dat de socialistische vakbondscultuur van het Limburgse bekken nog niet gestabiliseerd was. Zo organiseerde de Poolse migrantengemeenschap bij de in 1920 opgestarte steenkoolmijn de Hainaut (Borinage), die qua afkomst en samenstelling sterk analoog was aan de Poolse mijnwerkersgemeenschappen in Winterslag en Eisden, zich niet onder de banier van de Mijnwerkerscentrale. Het Boreinse socialisme bood deze Poolse arbeidsmigranten geen enkele opening. In het Limburgse mijnbekken was er nog geen etnische groep die het socialistische vakbondswerk monopoliseerde en zo konden de immigranten, met respect voor hun eigenheid, deze vakbond helpen opbouwen. Het unieke succes van de Limburgse Mijnwerkerscentrale onder de immigranten was evenwel van korte duur. In 1929 werden, als gevolg van wijzigingen zowel in de krachtsverhoudingen in België - een ruk naar rechts - als in de mi- grantengemeenschappen - de radicale koerswijziging van de communistische beweging met de Klasse tegen Klasse-strategie - vreemdelingen om politieke redenen massaal uitgewezen. Terwijler tor 1928 elk jaar slechts enkele vreemdelingen in België om politieke redenen het land moesten verlaten, werden in 1929 meer dan 200 en in 1931 zowaar 400 'subversieve' vreemdelingen uitgewezen. Deze repressie verlamde de werking van de Mijnwerkerscentrale onder de migranten in het Limburgse bekken. Zelfs de afgevaardigde van de Poolse arbeiders in het regionaal bestuur van de Limburgse mijnwerkerscentrale werd uitgewezen.

Vakbondswerk bleek voldoende om uitgewezen te worden ${ }^{(28)}$. Het multi-etnische vakbondswerk in Limburg werd zwaar gehypotheceerd door het repressieve staatsoptreden. De kwetsbare juridische positie van de buitenlandse arbeiders betekende de doodsteek voor het Limburgse multietnische socialisme. 
In 1930 was het multi-etnische vakbondswerk definitief dood en begraven. Ondanks de stijgende tewerkstelling van buitenlandse arbeiders in de mijnsector werd geen ernstige analyse gemaakt van dit falen ${ }^{(29)}$. De Mijnwerkerscentrale verklaarde de ontgoochelende resultaten van haar propaganda onder de immigranten - zowel vreemdelingen als Vlamingen - door de achterlijke mentaliteit van deze arbeiders ${ }^{(30)}$. De Luikse Mijnwerkerscentrale beschouwde de organisatie van vreemdelingen als een hopeloze onderneming en voerde in 1930 zelfs geen enkele propaganda meer onder immigranten ${ }^{(31)}$. Dat de inspanningen van de vakbond misschien ontoereikend waren werd nauwelijks geuit ${ }^{(32)}$. Dat de basis nauwelijks haar rangen had opengesteld voor de nieuwkomers werd ook niet geopperd. Dat het juridisch statuut van de buitenlanders hen niet beschermd had tegen een repressief staatsoptreden was blijkbaar niet relevant...

DeMijnwerkerscentrale bezon zichopnieuwover haar werking. De socialistische vakbond zag op lange termijn het dreigende gevaar van een steeds aangroeiende massa buitenlandse mijnwerkers. Degeringe resultaten van haar propaganda onder deze vreemdelingen zorgden ervoor dat ze, teneinde haar machtsbasis in de mijn niet kwijt te. spelen, de Belgische arbeiders tot ruggengraat van haar syndicale macht wilde maken:

"Les ouvriers belges, de plus en plus formeront les cadres de la main-d'oeuvre minière, s'ils sont bien unis, leurforce sera très grande; constituant ensemble les bases de la production, on devra compter avec eux... Tout en essayant de faire l'éducation des ouvriers étrangers qui nous arriveront de plus en plus nombreux, nous devons renforcer chez les mineurs de nationalité belge, l'esprit d'union et d'indépendance." (33)

In het Limburgse betekende deze strategie een principiële koerswijziging voor de Mijnwerkerscentrale. Het zich afwenden van de buitenlandse immigranten als partner in de vakbondswerking maakte dat deze centrale definitief in de minderheidspositie werd gedrongen, ze organiseerde immers tot dan toe nauwelijks Vlaamse mijnwerkers (34).

Hetorganiseren van de Vlaamse arbeiders in Limburg was het monopolie van de Vrije Mijnwerkers. De christen-democratische mijnwerkersbond had reeds begin jaren '20 de strategische keuze gemaakt zich te ontwikkelen tot een Vlaamse organisatie. De Vrije Mijnwerkers hadden zich als taak gesteld van dit mijnbekken een katholiek, Vlaams en christen-democratisch bastion te maken. Buitenlanders werden, gezien het manifest tekort aan gekwalificeerde arbeidskrachten, noodgedwongen getolereerd, maar het einddoel was ofwel ze te vervlaamsen of ze te verwijderen. Het vakbondswerk van de Vrije Mijnwerkers onder de buitenlanders lijkt, na een kortstondig succes, hierdoor op termijn sterk aan dynamisme ingeboet te hebben. De buitenlandse migranten werden door de christen-democratische beweging niet beschouwd als een groep die collectieve rechten kon opeisen ${ }^{(35)}$. Enkel via een individuele assimilatie konden ze volwaardige leden worden. De Vrije Mijnwerkers konden in Limburg evenwel een belangrijke aanhang werven. Immers heel wat mijnwerkers van Vlaamse origine, die in Wallonië de mijnwerkersstiel hadden geleerd, vestigden zich in het Limburgse bekken. Zokonden de Vrije Mijnwerkers de vruchten plukken van hun propaganda onder de Vlaamse mijnwerkers in Wallonië. Daarmee was slechts een minderheid van de Vlaamse arbeiders in de Limburgse mijnindustrie georganiseerd. De lokale arbeiders bleven afzijdig. $Z$ ij waren veelal ongekwalificeerde hulpkrachten, keuterboeren voor wie het mijnwerk een bijberoep was. $\mathrm{Zij}$ hadden hun lot (nog) niet met de mijnindustrie verbonden en vakbondswerk was hen totaal vreemd. Slechts tijdens de crisisjaren, toen bleek dat het mijnwerk een zekere bron van inkomen kon bieden, besloten een groeiend aantal Limburgers 
het landbouwwerk te ruilen voor het mijnwerk. $Z_{i j}$ werden toen van boeren-mijnwerkers mijnwerkers-boeren. Deze omschakeling was in deze crisistijd slechts mogelijk door het afstoten van buitenlandse arbeiders. De lokale arbeiders kregen bij het opeisen van de arbeidsplaatsen de volle steun van de Vrije Mijnwerkers. Deze nieuwe mijnwerkers vervoegden dan ook massaal de rangen van deze organisatie.

Dat internationale of zelfs nationale solidariteit ook onder de socialistisch georganiseerde mijnwerkers nauwelijks leefde bleek overduidelijk bij het uitbreken van de crisis. Reeds begin 1932, bij de spontane stakingen in de Borinage naat aanleiding van de eerste ontslagen onder de mijnwerkers, stelden de lokale mijnwerkers als centrale eis de verdeling van het beschikbare werk onder de autochtone arbeiders. Deze eis was zowel gericht tegen hun buitenlandse, als hun Vlaamse collega's. De Mijnwerkerscentrale kon dit lokaal protectionisme nier steunen en nam in het officiële eisenplatform enkel het ontslag van de vreemdelingen op. In de daaropvolgende crisisjaren was de organisatie van de buitenlandse immigranten voor geen van beide vakbonden nog een punt. $Z \mathrm{ij}$ ijverden enkel voor het gedwongen ontslag van de buitenlandse mijnwerkers ten voordele van de Belgische arbeiders.

De economische heropleving van 1936-1937 maakte dat er volgens het mijnpatronaat een tekort aan arbeidskrachten was in de mijnsector, dat enkel kon opgevangen worden door het aantrekken van buitenlandse arbeidskrachten. De Mijnwerkerscentrale aanvaardde deze logica. $\mathrm{Zij}$ erkende dat er een trend was onder Belgische arbeiders om de mijnarbeid de rug toe te keren en dat het aanwerven van immigranten de enige op. lossing was. De Vrije Mijnwerkers daarentegen wezen deze logica af en pleitten voor een revolutionaire oplossing. De schaarste op de arbeidsmarkt moest door de mijnwerkers uitgebuit worden door gevoelig betere arbeidsvoorwaarden af te dwingen. Met deze hogere lonen zou de mijnar- beid heel wat aantrekkelijker worden voor de Vlaamse arbeiders. Vlaanderen had immers nog belangrijke arbeidsoverschotten, vooral in WestVlaanderen. De mijnarbeid moest aantrekkelijker gemaakt worden zodat de werkloze of ondertewerkgestelde Vlamingen hun lot wensten te verbinden met de mijnindustrie. De Belgische mijnindustrie die sowieso al competitief uiterst zwak stond weigerde een dergelijke kostenverhoging te aanvaarden en, met de goedkeuring van de staat en de Mijnwerkerscentrale, werden tienduizend arbeidskrachten gerekruteerd in Centraal en Oost-Europa.

De Mijnwerkerscentrale die de structurele nood aan immigranten in de mijnindustrie erkende nam de organisatie van deze nieuwe immigranten ter hand. Jeanne Pirotte werd vrijgesteld voor het organiseren van de Polen ${ }^{(36)}$. De Poolse vakbondsleden mochten zich organiseren binnen Poolse secties. De in ' 37 in Polen gerekruteerde arbeiders waren vooral mijnwerkers die niet alleen hun arbeidskwalificaties naar België brachten, maar ook hun syndicale traditie. Zij moesten nauwelijks aangespoord worden om zich aan te sluiten bij de mijnwerkersvakbond van hun nieuwe gastland. Eind' 37 waren er reeds een paar duizend Polen ingeschreven bij de Mijnwerkerscentrale ${ }^{(37)}$. Het multi-etnische experiment van de Limburgse mijnwerkerscentrale werd evenwel niet herhaald. De Poolse secties waren louter aanhangsels van de plaatselijke afdelingen. Er was geen enkele institutionele integratie van de Poolse mijnwerkers in de vakbondsstructuur voorzien. Toen zij eind ' 37 zelf hun krachten wilden bundelen werd hier door de vakbondstop uiterst terughoudend op gereageerd ${ }^{(38)}$. Wanneer in '38 tijdelijke werkloosheid heerste in de mijnsector bleek dat niet alleen de Vrije Mijnwerkers, maar ook de Mijnwerkerscentrale de repatriëring van de Polen niet ongenegen was. Daarenboven hadden de vakbonden het recht op werkloosheidssteun voor de Poolse mijnwerkers niet kunnen afdwingen. Het hek was hiermee van de dam. De Polen verlieten even massaal als ze 
toegetreden waren de Mijnwerkerscentrale en de Poolse secties werden opgeheven ${ }^{(39)}$.

De vakbonden waren er in het interbellum niet in geslaagd zich als belangenverdediger van een etnisch heterogene arbeidersgroep op te werpen. Reeds in de jaren '20 hadden de Vrije Mijnwerkers ervaren dat een louter multicultureel beleid niet voldoende was om immigranten te verenigen binnen de vakbond. Immigranten werd geen enkele inspraak gegund en onder meer daardoor werd geen rekening gehouden met hun belangen. Integendeel de belangen van etnische minderheden werden opgeofferd. Het afwijzen door de vakbonden van een multi-etnisch arbeidsfront legde een zware hypotheek op de toekomst. De Belgische economie had immers in toenemende mate nood aan buitenlandse arbeidskrachten. Dadelijk na de Tweede Wereldoorlog zullen de beide vakbonden en in het bijzonder de christendemocratische de scherpste kanten van hun discriminerend beleid afvijlen. De beide vakbonden bouwden daarbij een multiculturele werking uit die heel wat aantrekkelijker werd door de buitenlandse arbeidskrachten mee te laten genieten van de weldaden van de Belgische welvaartsstaat. Immigranten, alhoewel structureel noodzakelijk voor de Belgische economie, bleven evenwel ook voor de traditionele vakbonden tweederangsarbeiders ${ }^{(40)}$. Slechts in de volgende decennia zal hier langzaamaan verandering in komen.

(1) Het onderzoek voor deze bijdrage was slechts mogelijk door de steun van de Humboldt Stiftung en het IMIS.

(2) Een Europees voorbeeld van een gescheiden syndicalisatie van een etnische minderheid die het arbeidersfront versterkte is de organisatie van de Poolse arbeidsmigranten in het Ruhrbekken in een Poolse vakbond ZPP. KLESSMANN Christoph, Polnische Bergarbeiter in Ruhrgebiet 1870-1945. Soziale Intgegration und nationale Subkultur einer Minderheit in der deutschen Industriegesellschaft, Cöttingen, Vandenhoeck \& Ruprecht, 1978.

(3) Frank CAESTECKER, Alien Policy in Belgium, 18301940. The Creation of Guest Workers, Refugees and IIlegal Immigrants, European University Institute, niet gepubliceerde doctoraalscriptie, 1994; LEBOUTTE René,
Reconversions de la main-d'oeuvre et transition démographique. Les bassins industriels en aval de Liège XVIle-XXe siècles, les Belles Lettres, Paris, 1988.

(4) Voor het volfedige panorama zie Caestecker (1994). Zie ook het artikel van Morelli in dit nummer.

(5) Le Franc Mineur, III, 13, p.7.

(6) De Gids op Maatschappeliik Gebied, 1920, 4, p. 198.

(7) QUAIRIAUX, La présence flamande dans le Centre, in: Mémoires d'une région. Le Centre (1830-1914), Morlanwelz, 1984 , p. 200 . Het is verbazend vast te stellen dat historici nauwelijks enige aandacht hebben besteed aan de vestiging van Vlaamse arbeidsmigranten in Wallonië, met uitzondering van het onderzoek van Quairiaux. Vergelijk dit met de migratie naar Frankrijk en in het bijzonder de migratie van de Franschmannen die niet alleen op een wetenschappelijke belangstelling kon rekenen (Schepens, ... Woestenberg) maar waarvan de herinnering wordt gekoesterd in de vorm van een museum, tentoonstellingen en monumenten.

(8) L'ouvrier mineur, XX, 1, 1924 en XXIII, 2, 1927, p. 29; VAN BELLE, Les Travailleurs Flamands dans la Province de Liège, in: Premiers Congrès des socialistes wallons, Liège, 1938, p.317.

(9) VAN BELLE, Les Travailleurs Flamands [...], p.318.

(10) De Mijnwerkerscentrale stelde in ieder geval fondsen ter beschikking voor de aanstelling van een Vlaamse propagandist voor het Luikse mijnbekken. AMSAB, Papieren Nauwelaerts, Centrale des Mineurs de Liège. Comité exécutif 31.10.1936 en 22.11.1937; Assemblée centrale, 25.11.1937; Volksgazet, 7.10.1936.

(11) Le Franc Mineur, II, 1923, 4, p.4.

(12) C. SUYVOET, Rapport sur la main-d'oeuvre étrangère, in: P. VAN MALDERE, Le problème des migrations ouvrières, Bruxelles, 1925, p.60; zie ook De Diamantbewerker, VIII, 13.2.1927, 7, p.2.

(13) DABROWKSI, Spoldzielcza Belgia (wrazenia z wycieczki), Warszawa, 1927, p.73.

(14) De Belgische Vakbeweging, 1926, 26, pp.388-389. Sprawozdane komisje centralnej Zwiakow zawodowych z dzialalnosci i stanu zwiazkow zawodowych w Polsce $w$ latach 1925-1928. Warschau, 1929, p.65.

(15) VAN MALDERE, Le problème [...], in: De Belgische Vakbeweging, 18.12.1926, 22, p.388. L'ouvrier mineur, XXV, april 1929, p.44. De Belgische Vakbeweging, 3.12.1927, 25, p.162.

(16) De Volkswil, 16.9.1928 en 25.11.1928. L'ouvrier mineur, XXIIII, 1927, p.30 en XXV, 1929, 4, p.44

(17) De Volkswil, 2.9.1928; 23.3.1928; 10.6.1928. De historiografie van het Limburgse mijnbekken negeert deze weliswaar kortstondige doorbraak van een multietnisch socialisme in het Limburgse mijnbekken. Buitenlanders worden er geportretteerd als willoze slachtoffers van het mijnpatronaat. Een vertekend beeld dat onder meer een gevolg is van het louter steunen op Belgische bromnen.

(18) Clos Pracy, 5.5.1928. Merk op dat de categorie Vlaming niet gebruikt werd, terwijl wel Slovenen en Tsjechen opgenoemd werden. Over de afwezigheid van de Vlamingen in de socialistische bond zie verder.

(19) "Les travailleurs belges...au lieu de traiter les travailleurs étrangers "en camarade" et les aider à se défendre contre les patrons, les repoussent, les méprisent et parfois les bafouent" La Voix Communiste, 11.1.1931/3. 
(20) Wychodzca, 1929, 52, p.12.

(21) "Les ouvriers étrangers... deviennent un danger...pour notre vieille classe ouvrière des mines, prudente et instruite par une longue tradition." L. PIERARD, in: Le Peuple, 22.3.1930. Zie ook Le Peuple, 8.10.1922 en 30.3.1930; La Wallonië, 9.10. 1923; L'ouvrier mineur, XIX, april 1923 en XX, 1924, 1, p.2.

(22) A. DELATTRE, in: Parlementaire Handelingen Kamer, 24.7.1924, p.2223 en 7.1924, p.1832: "ces étrangers ne savent pas travailler au fond de la mine" Assemblée plénière, 22.7.1924. Archief van de Mijnwerkerscentrale, n3. Livre des procès-verbaux de la Centrale des Mineurs du Borinage.

(23) L. PIERARD, in: Le Peuple, 22.3.1930 en Le Peuple 30.3.1930; 23.7.1929/2.2. VAN MALDERE, Le Problème [...], p.76; "Archives de l'Etat", Liège, fonds Gosson, 583. Klachten van de vakbondsdelegatie, 18.6.1924, 3.12.1924, 4.1.1929 en 22.1.1929.

(24) DELATTRE: "notre classe ouvrière, si pure et si honnête, est attaquée par le virus de l'immoralité... La main-d'oeuvre étrangère jette...le désarroi moral." Parlementaire Handelingen Kamer, 24.7.1924, p.2223. Le Peuple, 28.6.1924/1, 3; La Wallonië, 21.11.1922. La lutte contre le chômage, XIII, 1924, 2, p.49 en XIV, 3.1925:

(25) "La plupart de ces migrants sont d'un degré de civilisation de beaucoup inférieur au nôtre... Ils semblent parfois avoir perdu toute attache avec l'humanité. Ils n'ont aucun souci intellectuel ou moral. Lorsque leurs besoins matériels sont à peu près satisfaits, ils cherchent l'oubli de leur misère dans l'absorption de bières à haute densité ou de vins frelatés... Après avoir dépensé le samedi soir ou dans la journée du dimanche ce qui leur reste de leur paie, ils en viennent très souvent aux mains, le sang coule, on s'y sent guère en sûrete, ces gens jouant volontiers du revolver. "Rapport de la Fédération des Syndicats du Centre, in: VAN MALDERE, Le Problème [...], p.63, ook p.67 en 35; La lutte contre le chômage, XIV, mars 1925 , p.37. P. VAN MALDERE, in: Belgische Vakbeweging, 1931, 110, pp.198-200. "Ces incivilisés, sauvages marocains ou polonais ivres", J. DUMOULIN, in: Le Prolétaire, VIII, $371,5.6 .1926$, p.4.

(26) Voor xenofobie in het Limburgers mijnbekken zie Le Franc-Mineur, XII, 1931, 7, p.3 en mijn interviews met vooral Poolse mijnwerkers. In de Volkswil, weekblad der Limburgse werkliedenpartij van 1928 en 1929 werd geen enkele negatieve opmerking genoteerd over de buitenlandse arbeiders.

(27) In november 1927 was $8 \%$ van de mijnwerkers in de Waalse bekkens van buitenlandse nationaliteit, tegen $21 \%$ in het Limburgse bekken.

(28) "Onze vakbond wordt aangevallen door de Belgische autoriteiten. Onze heel actieve kameraad Roman Kusek werd beschuldigd Communist te zijn, alhoewel hij in het bestuur van onze vakbond zetelde en een vitgesproken socialist was. Niets kon helpen, zelfs niet de interventie van onze parlementsleden," C. SUYVOET, in: Prawo Ludu, VI, 1930, 22, p.1. Of louter vakbondswerk een uitwijzing kon opleveren is onduidelijk, enkel een nauwgezet onderzoek van de uitwijzingsbeslissingen van de Openbare Veiligheid kan hierop een antwoord geven. In tegenstelling tot de linkse syndicalist C. Suyvoet beweerde de voorzitter van de Mijnwerkerscentrale Dejardin dat er onder de Poolse arbeiders geen loyale socialisten waren. Robotnik (PPS-orgaan), $25.5 .1930 / 3,1-2$.
(29) In januari 1931 was $16 \%$ van de mijnwerkers in Wallonië en $29 \%$ in Limburg van buitenlandse nationaliteit, samen 30.000 personen.

(30) "De buitenlandse mijnwerkers zijn een onbewuste, ongeletterde massa van Lumpenproletariaat zonder enig karakter." De Volkswil, socialistisch weekblad voor Limburg en Luik 3.1.1932.

(31) "Depuis 1924, la Centrale a usé de mêmes moyens de propagande auprès des étrangers de plusieurs langues que ceux employés à l'égard des flamands, pour n'obtenir que le même résultat... La Centrale a momentanément cessé toute action auprès de ces gens. " Centrale Syndicale regionale des mineurs du bassin de Liège, Rapport et bilan annuel 1931, p.35.

(32) Voor uitzonderlijke uitingen van zelfkritiek: "On est en droit de dire que ce que l'on a fait est insuffir sant...selon nous, on manque d'unité dans l'action ainsi que d'éléments préparés spécialement pour cette besogne délicate. Qui va apprendre le polonais, l'italien, le flamand, etc." I. DEDOYARD, in: L'ouvrier mineur, XXVII, 7.1931, p.133, zie ook DELWART (Borinage), in: Vooruit, 11.5.1931/5.

(33) Nos effectifs, s.d., KADOC, Papieren Broekx, 5.2.3.1. (Verslag van de socialistische mijnwerkerscen trale, 1931?). Ten dele gepubliceerd in: L'ouvrier mineur, 1-3.1931, pp.44-45.

(34) Archieven KPB, microfilms Instituut Marxisme-Leninisme Moskou. Commission syndicale centrale, 15.11.1929.

(35) Zo hadden de Poolse mijnwerkers in Limburg zich autonoom georganiseerd in kassen van wederzijdse hulp. Zij stelden, waarschijnlijk in 1929, aan de Limburgse christelijke mutualiteit voor om op te gaan in deze christen-democratische organisatie. De Poolse organisaties rekenden erop dat zij dan een afgevaardigde konden delegeren in het bestuur, dit werd evenwel afgewezen. Antwerpse consulaat, Archivum Akt Nowych Warschau, Ministerstwo Spraw Zagranicza, 10.069 Rapport over de situatie en de emigratieconjunctuur in België in de tweede helft van 1930, p.22.

(36) AMSAB, Fonds Nauwelaerts, Luikse mijnwerkerscentrale, comité exécutif 8.6.1937.

(37) L'ouvrier mineur, XXXIII, 10, 1937, p.3; La Voix du Peuple, 2.9.1937, 4/3.

(38) Dziennik Ludoowy, 4.12.1937. "Gillot signale que les étrangers insistent pour qu'on les réunisse et un d'entre eux se propose comme interprête... Le comité lui conseille d'agir avec la plus grande prudence". $A M S A B$, Fonds Nauwelaerts, Luikse mijnwerkerscentrale, comité exécutif 21.2 .1938 .

(39) L'ouvrier mineur, XXXIV, 12.1938, p.5, AMSAB, Fonds Nauwelaerts, Luikse mijnwerkerscentrale, comité exécutif, 11.7.1938. politiearchief Genk, klacht van $C$. SUVOET 1.7.1939 $\mathrm{nr} .723$.

(40) L'ouvrier mineur, 7.1948, p.2, Rapport général des travaux de la journée d'étude pour les travailleurs DP du 14.11.1948. Archief Hoog Commissariaat voor de Vluchtelingen Brussel, D44 PR2D. Tenwijl de traditionele mijnwerkersvakbonden vanaf 1946-1947 een categorische werking voor de immigranten uitbouwden was de communistische eenheidsvakbond hiervan af kerig. Deze vakbond bepleitte wel internationale solidariteit, maar deed blijkbaar geen enkele poging om via afzonderlijke afdelingen de buitenlanders, onder wie heel wat militanten van de KPB, te mobiliseren. 